\title{
PHYSICO-CHEMICAL CHANGES IN KARKADE (HIBISCUS SABDARIFFA L.) SEEDLINGS RESPONDING TO SALT STRESS
}

\author{
ABDELnASSER GALAL* \\ Botany Department, Faculty of Science, Sohag University, 82524 Sohag, Egypt
}

(Received: August 15, 2016; accepted: October 26, 2016)

\begin{abstract}
Salinity is one of the major abiotic stress factors affecting series of morphological, physiological, metabolic and molecular changes in plant growth. The effect of different concentrations $(0,25,50,100$ and $150 \mathrm{mM}$ ) of $\mathrm{NaCl}$ on the vegetative growth and some physiological parameters of karkade (Hibiscus sabdariffa var. sabdariffa) seedling were investigated. $\mathrm{NaCl}$ affected the germination rate, delayed emergence and retarded vegetative growth of seedlings. The length of seedling as well as the leaf area was significantly reduced. The fresh weight remained lower in $\mathrm{NaCl}$ treated seedlings compared to control. $\mathrm{NaCl}$ at 100 and $150 \mathrm{mM}$ concentrations had significant effect on the dry matter contents of the treated seedlings. The chloroplast pigments in the treated seedlings were affected, suggesting that the $\mathrm{NaCl}$ had a significant effect on the chlorophyll and carotenoid biosynthesis. The results showed that the salt treatments induced an increase in proline concentration of the seedlings. The osmotic potential ( $\psi \mathrm{s})$ of $\mathrm{NaCl}$ treated seedlings decreased with increasing $\mathrm{NaCl}$ concentrations. Salt treatments resulted in dramatic quantitative reduction in the total sterol percent compared with control ones. Salt stress resulted in increase and decrease of $\mathrm{Na}^{+}$and $\mathrm{K}^{+}$ions, respectively. $\mathrm{NaCl}$ salinity increased lipid peroxidation. SDSPAGE was used to evaluate protein pattern after applying salt stress. High molecular weight proteins were intensified, while low molecular weight proteins were faint. $\mathrm{NaCl}$ at 100 and $150 \mathrm{mM}$ concentration distinguished with new protein bands. Salt stress induced a new peroxidase bands and increased the band intensity, indicating the protective role of peroxidase enzyme.
\end{abstract}

Keywords: Carotenoids - chlorophyll - karkade - peroxidase - pigments - salt stress - seedling emergence

\section{INTRODUCTION}

Plants have evolved complex mechanisms for adaptation to osmotic and ionic stresses caused by high salt. These mechanisms include osmotic adjustment by accumulation of compatible solutes, such as proline, glycine, betaine, polyols, sugar alcohols and soluble sugars, and lowering the toxic concentration of ions in the cytoplasm by restriction of $\mathrm{Na}^{+}$influx or its sequestration into the vacuole and/or its extrusion [44]. There are evidences showing that salinity changes photosynthetic parameters, includ-

\footnotetext{
*E-mail address: nasergalal@gmail.com
} 
ing osmotic and leaf water potential, transpiration rate, leaf temperature, and relative leaf water content [47].

Salinity alters a wide array of metabolic processes in growing plants and induces changes in contents and activities of many enzymes [29, 49]. Salinity appears to affect two plant processes: water relations and ionic relations. During initial exposure to salinity, plants experience water stress, which in turn reduces leaf expansion. During long-term exposure to salinity, plants experience ionic stress, which can lead to premature senescence of adult leaves $[13,24]$. Salinity is expressed by a series of morphological, physiological, metabolic and molecular changes that cause delayed germination, poor stand establishment [5,39], high seedling mortality, stunted growth and lower yields $[4,35]$.

Elevated $\mathrm{NaCl}$ causes an increase in $\mathrm{Na}^{+}$concentration and a decrease in $\mathrm{K}^{+}$and $\mathrm{Ca}^{2+}$ concentration [44]. In addition, accumulation of $\mathrm{Na}^{+}$ions changes ion balance such as $\mathrm{Na} / \mathrm{Ca}$ and $\mathrm{K} / \mathrm{Na}$ ratio in plant cells under saline condition. A high $\mathrm{Na} / \mathrm{Ca}$ ratio results in increased cell permeability [32]. Ion disorders caused from salinity may also lead to changes in plant lipid metabolism [37]. When examining the effects of environmental stresses on plant membranes, researchers have also measured the products of lipid peroxidation, such as malondialdehyde (MDA) and/or ethane [48].

Roselle (Hibiscus sabdariffa L.) belongs to the family Malvaceae, locally called "karkade", is an important annual crop grown successfully in tropical and sub-tropical climates [33]. The commercially important part of the plant is the fleshy calyx (sepals) surrounding the fruit (capsules). The whole plant can be used as beverage, or the dried calyces can be soaked in water to prepare a colorful cold drink, or may be boiled in water and taken as a hot drink. It also has some medicinal properties [19]. The seeds contain $17.8-21 \%$ non-edible oil and $20 \%$ protein, and are sometimes used for animal feed [20]. The purpose of the present study was to determine some morphological, physiological and molecular changes during seed germination of Karkade (Hibiscus sabdariffa var. sabdariffa) under $\mathrm{NaCl}$ salinity stress.

\section{MATERIALS AND METHODS}

\section{Plant material preparation}

\section{Germination test}

Healthy and uniform seeds of Karkade (Hibiscus sabdariffa var. sabdariffa) were kindly provided by the Vegetable Crop Department, Agricultural Research Center, Ministry of Agriculture (Giza, Egypt). Surface sterilization was carried out with ethanol $70 \%$ followed by $10 \%$ commercial bleach then rinsed 3 times with sterile distilled water. Seeds were subsequently placed in sterile plates containing half-strength MS [35] medium supplemented with $2 \%$ sucrose, $0.4 \%$ agar and different concentrations $(0,50,100$ and $150 \mathrm{mM})$ of $\mathrm{NaCl}$. Germination was performed in a growth chamber for two weeks under controlled environmental conditions of temperature $\left(28 \pm 2{ }^{\circ} \mathrm{C}\right)$, 
photoperiod regime $(16 \mathrm{~h} /$ day $)$, irradiance intensity $\left(50 \mu \mathrm{E} \mathrm{m}^{-2} \mathrm{~S}^{-1}\right)$ and humidity $(70 \%)$. For each experiment 40 seeds were used and each experiment was made in triplicate. Daily observations were made on radicle emergence. Seed germination percentage was calculated using the following formula: Germination $\%=$ Number of germinated seeds/total number of seeds $\times 100$. Speed of germination was calculated by the following formula given by Czabator [17]. Speed of germination $=\mathrm{n} 1 / \mathrm{d} 1+\mathrm{n} 2 /$ $\mathrm{d} 2+\mathrm{n} 3 / \mathrm{d} 3+-------$. . Where, $\mathrm{n}=$ number of germinated seeds, $\mathrm{d}=$ number of days.

\section{Measurement of seedling height, fresh and dry weight and leaf area}

Morphological parameters such as seedling height and fresh weight were measured in fresh samples. The fresh weight of each sample with its leaves was determined, then the samples were oven-dried at $80{ }^{\circ} \mathrm{C}$ and the dry weight was determined. Leaf area was measured by an area meter (Area Meter CI, 202).

\section{Estimation of photosynthetic pigments}

The photosynthetic pigments (chlorophyll a, chlorophyll $\mathrm{b}$ and carotenoids) were determined spectrophotometrically (Spekol 11, Carl Zeiss, Jena, Germany) according to Metzner et al. [35].

\section{Determination of proline}

Proline was determined by the ninhydrin method described by Bates et al. [11]. In this method, proline was extracted from $0.5 \mathrm{~g}$ of fresh leaf tissue into $10 \mathrm{ml}$ of $3 \%$ sulfosalicylic acid and filtered through Whatman No. 42 filter papers and determined in Shimadzu UV-1201 model spectrophotometer.

\section{Estemation of sterol}

Total lipids were fractionated according to the method of Farag et al. [21]. Estimation of total sterol was carried out using Perkin-Elmer 3920B gas chromatograph equipped with a flame ionization detector. A glass column $(2 \mathrm{~m} \times 2 \mathrm{mmID})$ packed with $3 \%$ (w/w) OV-I? of 80-100 mesh Gas-Chrom Q, was used isothermally at $240{ }^{\circ} \mathrm{C}$. The carrier gas was helium at a flow rate of $40 \mathrm{ml} / \mathrm{min}$. Injector and detector temperatures were 225 and $245^{\circ} \mathrm{C}$, respectively. For quantification, 5ct-cholestane was used as internal standard, and sterols were identified by cochromatography using authentic standards [1]. 


\section{Determination of leaf water relations}

Leaf samples were frozen in liquid nitrogen, and stored at $-20{ }^{\circ} \mathrm{C}$. Tissues were thawed and centrifuged at $1,200 \times g$ for $25 \mathrm{~min}$ at $4{ }^{\circ} \mathrm{C}$ to extract the cell sap. Osmotic potential $(\psi \mathrm{s})$ of the cell sap was measured using a vapor pressure osmometer (model 5,500, Wescor, Logan, UT, USA). Osmotic adjustment (OA) was calculated as the differences in $\psi \mathrm{s}$ between salinized and control plants.

\section{Determination of ion content}

For ions determination, fresh leaf samples were extracted in concentrated $0.1 \mathrm{~N}$ nitric acid. $\mathrm{N}, \mathrm{K}$ and $\mathrm{Ca}$ contents were determined by flame photometry in samples from leaves [5].

\section{Lipid peroxide content (MDA)}

Lipid peroxidation was measured as the amount of MDA determined by the thiobarbituric acid (TBA) reaction [27]. Frozen samples were homogenized in a pre-chilled mortar with two volumes of ice-cold $0.1 \%(\mathrm{w} / \mathrm{v})$ tricloroacetic acid (TCA) and centrifuged for $15 \mathrm{~min}$ at $15,000 \times \mathrm{g}$. Assay mixture containing $1 \mathrm{ml}$ aliquot of the supernatant and $2 \mathrm{ml}$ of $0.5 \%(\mathrm{w} / \mathrm{v})$ thiobarbituric acid in $20 \%(\mathrm{w} / \mathrm{v})$ tricloroacetic acid (TCA) was heated to $95^{\circ} \mathrm{C}$ for $30 \mathrm{~min}$ and then rapidly cooled in an ice-bath. After centrifugation $\left(10,000 \times g\right.$ for $10 \mathrm{~min}$ at $\left.4{ }^{\circ} \mathrm{C}\right)$, the supernatant absorbance $(532 \mathrm{~nm})$ was read and values corresponding to non-specific absorption $(600 \mathrm{~nm})$ were subtracted. The MDA content was calculated according to the molar extinction coefficient of MDA $\left(155 \mathrm{mM}^{-1} \mathrm{~cm}^{-1}\right)$.

\section{SDS-protein electrophoresis}

Protein extraction was performed using two-week-old seedlings. SDS polyacrylamide gel electrophoresis (SDS-PAGE) was performed for total proteins according to the method described by Laemmli [30].

\section{Isozyme analysis}

Isozyme extraction was performed using two-week-old seedlings as well as leaf tissues from $\mathrm{NaCl}$ treated plants. Tissue $(400 \mathrm{mg})$ was ground in $2 \mathrm{ml}$ extraction buffer $(0.1 \%(\mathrm{w} / \mathrm{v})$ Tris-citric acid, $\mathrm{pH} 7.5 ; 1 \%(\mathrm{w} / \mathrm{v})$ polyvinylpyrrolidone (PVP); $0.1 \%$ $(\mathrm{w} / \mathrm{v})$ ascorbic acid and $0.1 \%(\mathrm{w} / \mathrm{v})$ cysteine) and centrifuged at $5333 \times \mathrm{g}(\mathrm{JS}-5.2$ 
rotor), at $4{ }^{\circ} \mathrm{C}$ for $5 \mathrm{~min}$. Twenty $\mu 1$ of extracted samples were used for electrophoresis on native (-PAGE) gel according to the method of Stigmann et al. [45], using a Pharmacia electrophoresis apparatus (GE-4).

\section{Peroxidase detection}

Peroxidase enzyme activity was detected by incubating the native (-PAGE) gel in darkness for one hour at $37{ }^{\circ} \mathrm{C}$ in a mixture of $15 \mathrm{ml}$ of $10 \%$ benzidine (in $95 \%$ ethanol); $85 \mathrm{ml}$ of $1 \mathrm{mM}$ potassium acetate and $1 \mathrm{ml}$ of $1 \% \mathrm{H}_{2} \mathrm{O}_{2}(\mathrm{pH} 4.7)$. After the incubation period, the gel was rinsed in distilled water and fixed in $50 \%$ glycerol for one hour.

\section{Statistical analysis}

Data were statistically analyzed by calculating the means, standard deviation (SD) and the least significant difference (LSD) using the statistical package of SAS program, version 9.1 [41].

\section{RESULTS}

\section{Seed germination}

Seed germination studies showed that $\mathrm{NaCl}$ stress had a significant effect on seed germination. The germination percent decreased as the result of salinity stress/ increasing $\mathrm{NaCl}$ concentration in medium. Seed germinated percent of the seeds treated with $25,50,100$ and $150 \mathrm{mM}$ were $83.6,73.8,24.9$ and $11.7 \%$, respectively. Delaying of germination was observed in the salt stress treatments. The 125 and 150 $\mathrm{mM} \mathrm{NaCl}$ had a significant effect on the germination rate. Salt stress significantly affected the fresh weight and dry weight of seedlings. Elongation studies showed that $\mathrm{NaCl}$ had a significant effect on the lengths of seedlings (Table 1). Seedlings grown in media supplied with 25 or $50 \mathrm{mM} \mathrm{NaCl}$ were shorter, 12.63 and $7.35 \mathrm{~cm}$, respectively. They could develop their secondary leaves. Seedlings grown in media supplied with 100 and $150 \mathrm{mM} \mathrm{NaCl}$ were much shorter, 3.77 and $1.54 \mathrm{~cm}$, respectively. They could not even develop their secondary leaves. Seedlings could hardly growth at salinity higher than $150 \mathrm{mM}$ (Table 1). The leaf area of seedlings subjected to $\mathrm{NaCl}$ salinity stress were significantly affected. The leaf areas of seedlings treated with $25,50,100$ and $150 \mathrm{mM}$ salt were, $27.65,25.49,13.08$ and $7.13 \mathrm{~mm}^{2}$, respectively (Table 1). 
Table 1

Effects of $\mathrm{NaCl}$ on seed germination and growth of karkade seedling characteristics

\begin{tabular}{|c|c|c|c|c|c|c|}
\hline $\begin{array}{c}\text { NaCl treatment } \\
(\mathrm{mg} / \mathrm{L})\end{array}$ & $\begin{array}{c}\text { Germination } \\
(\%)\end{array}$ & $\begin{array}{c}\text { Speed } \\
\text { of germination }\end{array}$ & $\begin{array}{c}\text { Seedling fresh } \\
\text { weight }(\mathrm{g})\end{array}$ & $\begin{array}{c}\text { Seedling } \\
\text { dry weight } \\
(\mathrm{g})\end{array}$ & $\begin{array}{c}\text { Seedling } \\
\text { length }(\mathrm{cm})\end{array}$ & $\begin{array}{c}\text { Leaf area } \\
\left(\mathrm{mm}^{2}\right)\end{array}$ \\
\hline 0.0 & 100 & $0.76^{\mathrm{a}}$ & $42.8^{\mathrm{a}}$ & $9.2^{\mathrm{a}}$ & $14.94^{\mathrm{a}}$ & $36.73^{\mathrm{a}}$ \\
\hline 25 & 83.6 & $0.57^{\mathrm{b}}$ & $35.7^{\mathrm{b}}$ & $8.1^{\mathrm{a}}$ & $12.63^{\mathrm{b}}$ & $27.65^{\mathrm{b}}$ \\
\hline 50 & 73.8 & $0.38^{\mathrm{c}}$ & $23.4^{\mathrm{c}}$ & $7.5^{\mathrm{a}}$ & $7.35^{\mathrm{c}}$ & $25.49^{\mathrm{b}}$ \\
\hline 100 & 24.9 & $0.24^{\mathrm{d}}$ & $17.6^{\mathrm{d}}$ & $5.4^{\mathrm{b}}$ & $3.77^{\mathrm{d}}$ & $13.08^{\mathrm{c}}$ \\
\hline 150 & 11.7 & $0.12^{\mathrm{f}}$ & $12.8^{\mathrm{f}}$ & $3.7^{\mathrm{c}}$ & $1.54^{\mathrm{f}}$ & $7.13^{\mathrm{d}}$ \\
\hline LSD $(\alpha<0.05)$ & 11.3 & 0.09 & 2.58 & 1.3 & 1.17 & 3.43 \\
\hline
\end{tabular}

The experiment was conducted twice with 3 replicates/treatment. Mean values indicated by the same latter in the same column are not significant different $(\alpha \leq 0.05)$

Table 2

Effects of $\mathrm{NaCl}$ on chlorophyll (a), chlorophyll (b) and carotenoid contents of karkade leaves subjected to different concentrations $(0,25,50,100$ and $150 \mathrm{mM})$ of $\mathrm{NaCl}$

\begin{tabular}{|c|c|c|c|c|}
\hline \multirow{2}{*}{$\begin{array}{c}\text { Treatment of } \mathrm{NaCl} \\
(\mathrm{mM})\end{array}$} & \multicolumn{4}{|c|}{ Pigments content (mg/g fresh weight) } \\
\cline { 2 - 5 } & Chl a & Chl b & Total Chl & Carotenoids \\
\hline Control & $1.37 \pm 0.12$ & $0.93 \pm 014$ & $2.37 \pm 014$ & $0.38 \pm 0.05$ \\
\hline 25 & $1.02 \pm 0.07$ & $0.81 \pm 0.05$ & $1.83 \pm 014$ & $0.27 \pm 0.02$ \\
\hline 50 & $0.93 \pm 0.09$ & $0.64 \pm 0.04$ & $1.57 \pm 014$ & $0.21 \pm 0.04$ \\
\hline 100 & $0.43 \pm 0.02$ & $0.33 \pm 0.05$ & $0.76 \pm 014$ & $0.19 \pm 0.02$ \\
\hline 150 & $0.27 \pm 0.07$ & $0.13 \pm 0.03$ & $0.40 \pm 014$ & $0.11 \pm 0.03$ \\
\hline LSD & 0.17 & 0.05 & 0.24 & 0.04 \\
\hline
\end{tabular}

Data represented as means \pm SD followed by LSD test at $\alpha<0.01$.

Table 3

Effects of $\mathrm{NaCl}$ salinity on changes of $\mathrm{Na}^{+}, \mathrm{K}^{+}$and $\mathrm{Ca}^{2+}$ ions contents and $\mathrm{K}^{+} / \mathrm{Na}^{+}$and $\mathrm{Na}^{+} / \mathrm{Ca}^{2+}$ ratios in karkade seedlings

\begin{tabular}{|c|c|c|c|c|c|c|}
\hline $\mathrm{NaCl}(\mathrm{mM})$ & $\begin{array}{c}\mathrm{Na}^{+} \\
\text {(g/g f.w. })\end{array}$ & $\begin{array}{c}\mathrm{K}^{+} \\
\text {(g/g f.w. })\end{array}$ & $\mathrm{K}^{+} / \mathrm{Na}^{+}$ & $\begin{array}{c}\mathrm{Cl}^{-} \\
\text {(g/g f.w. })\end{array}$ & $\begin{array}{c}\mathrm{Ca}^{2+} \\
\text { (g/g f.w. })\end{array}$ & $\mathrm{Na}^{+} / \mathrm{Ca}^{2+}$ \\
\hline 0.0 & 0.430 & 1.453 & 3.38 & 0.570 & 1.643 & 0.261 \\
\hline 25 & 2.556 & 0.967 & 0.378 & 2.564 & 1.030 & 2.482 \\
\hline 50 & 4.346 & 0.845 & 0.194 & 3.432 & 0.920 & 4.724 \\
\hline 100 & 5.673 & 0.689 & 0.121 & 4.436 & 0.870 & 6.521 \\
\hline 150 & 6.123 & 0.545 & 0.089 & 5.053 & 0.630 & 9.719 \\
\hline LSD & 0.050 & 0.030 & 0.030 & 0.010 & 0.030 & 0.020 \\
\hline
\end{tabular}

Data represented as means followed by LSD test at $\alpha<0.01$. f.w.: fresh weight. 


\section{$\mathrm{NaCl}$ effects on the photosynthetic pigments}

$\mathrm{NaCl}$ affects on the photosynthetic pigments of leaves were examined (Table 2). Chlorophyll and carotenoid contents significantly decreased in $\mathrm{NaCl}$ treated seedlings. Chlorophyll b was more sensitive than chlorophyll a in the treated seedlings with $150 \mathrm{mM}$ salt. Chlorophyll a and b decreased to 0.27 and $0.13 \mathrm{mg} / \mathrm{g}$ fresh weight, respectively. The total chlorophylls decreased from $2.37 \mathrm{mg} / \mathrm{g}$ fresh weight at control to 0.40 at the highest $(150 \mathrm{mM})$ concentration of salinity (Table 2). Salinity had also a significant effect on carotenoid contents (Table 2).

\section{$\mathrm{NaCl}$ effects on the total sterol profile}

The results of this study showed dramatic quantitative reduction in the total sterol percent of the treated seedlings compared with control ones (Fig. 1). $\mathrm{NaCl}$ treatment significantly affected the total sterol percent in all concentrations $(25,50,100$ and $150 \mathrm{mM}$ ) tested (Fig. 1).

\section{$\mathrm{NaCl}$ effects on ions contents}

Under salinity conditions, $\mathrm{NaCl}$ concentrations showed a uniform increase in $\mathrm{Na}^{+}$ion and decrease in $\mathrm{K}^{+}$ion in stressed seedlings (Table 3 ). $\mathrm{K}^{+} / \mathrm{Na}^{+}$ratios of karkade seedlings treated with salted solution were lower than those of controls. From the aspect of $\mathrm{K}^{+} / \mathrm{Na}^{+}$ratios, differences among the treatments were significant. The lowest $\mathrm{K}^{+}$/ $\mathrm{Na}^{+}$ratio was found in $150 \mathrm{mM}$ treated seedlings. The ratio of $\mathrm{K}^{+} / \mathrm{Na}^{+}$decreased as the concentration of $\mathrm{NaCl}$ concentration increased. On the other hand, $\mathrm{NaCl}$ concentrations showed a uniform increase of $\mathrm{Na}^{+}$ion and decrease in $\mathrm{Ca}^{2+}$ ion contents in stressed seedlings. $\mathrm{Na}^{+} / \mathrm{Ca}^{2+}$ ratios of seedlings treated with the salt containing solu-

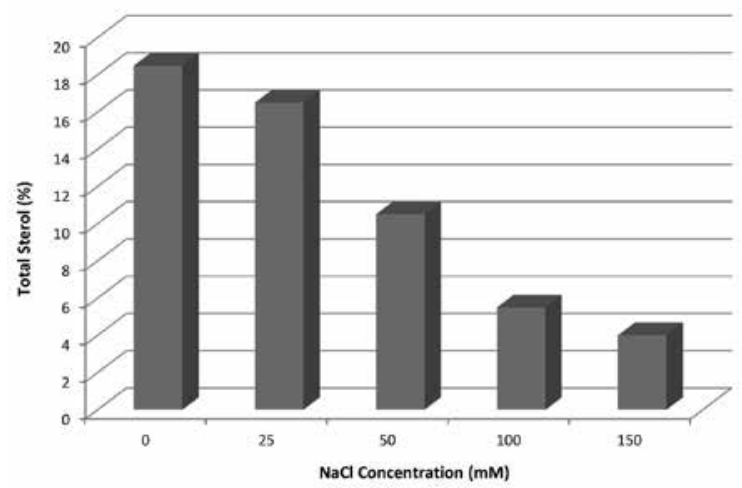

Fig. 1. Effect of different concentrations $(0,25,50,100$ and $150 \mathrm{mM})$ of $\mathrm{NaCl}$ on total sterol content in karkade seedlings. Percentage was calculated relative to the total unsaponifiable matters 
tion were higher than those of control ones. The ratio of $\mathrm{Na}^{+} / \mathrm{Ca}^{2+}$ increased as the concentration of $\mathrm{NaCl}$ concentration increased (Table 3).

\section{$\mathrm{NaCl}$ effects on the osmotic potential}

The osmotic potential ( $\psi \mathrm{s})$ of $\mathrm{NaCl}$ treated seedlings decreased with the increase of $\mathrm{NaCl}$ concentrations and the decrease was more pronounced at the highest concentration $(150 \mathrm{mM} \mathrm{NaCl})$ of salinity tested. Osmotic adjustment (OA) increased with the increase of $\mathrm{NaCl}$ concentration, and was more pronounced at the highest concentration $(150 \mathrm{mM})$ of $\mathrm{NaCl}$ (Table 4).

\section{$\mathrm{NaCl}$ effects on the lipid peroxide content (MDA)}

Damage by $\mathrm{NaCl}$ to cellular membranes due to lipid peroxidation as indicated by the accumulation of the malondialdehyde (MDA) levels was observed. The results showed that MDA level was significantly increased with the increase of $\mathrm{NaCl}$ concentrations. $\mathrm{NaCl}$ treatment significantly affected the malondialdehyde (MDA) levels in all concentrations tested. MDA amounts increased as the concentration of $\mathrm{NaCl}$ concentration increased. These increases of MDA were very clear in the treated seedlings with $150 \mathrm{mM} \mathrm{NaCl}$, while being the lowest in control one (Table 5).

\section{$\mathrm{NaCl}$ effects on proline concentration}

The results showed that the salt treatments induced an increase in proline concentration of the karkade seedlings (Table 6).

Table 4

Osmotic potential $(\psi s)$ and osmotic adjustment (O.A.) in karkade seedlings under different concentrations $(0,25,50,100$ and $150 \mathrm{mM})$ of $\mathrm{NaCl}$

\begin{tabular}{|c|c|c|c|c|c|}
\hline & \multicolumn{5}{|c|}{$\mathrm{NaCl}$ concentration (mM) } \\
\cline { 2 - 6 } & 0.0 & 25 & 50 & 100 & 150 \\
\hline$\Psi \mathrm{s}$ & 2.97 & -3.79 & $-5.21 ?$ & -6.45 & -8.94 \\
\hline OA & - & 1.42 & 2.66 & 5.15 & 6.43 \\
\hline
\end{tabular}

Table 5

Effects of $\mathrm{NaCl}$ salinity on MDA contents in karkade seedlings

\begin{tabular}{|l|c|c|c|c|c|}
\hline \multirow{2}{*}{} & \multicolumn{5}{|c|}{$\mathrm{NaCl}$ concentration $(\mathrm{mM})$} \\
\cline { 2 - 6 } & 0.0 & 25 & 50 & 100 & 150 \\
\hline MDA mol g FW & $2.453^{\mathrm{a}}$ & $2.765^{\mathrm{a}}$ & $3.062^{\mathrm{b}}$ & $4.439^{\mathrm{c}}$ & $5.536^{\mathrm{d}}$ \\
\hline
\end{tabular}

Mean values indicated by the same lower-case letters are not significantly different $(\alpha \leq 0.01)$. 
Table 6

Effects of $\mathrm{NaCl}$ on proline concentration of karkade seedlings treated with different concentrations $(0,25,50,100$ and $150 \mathrm{mM})$ of $\mathrm{NaCl}$

\begin{tabular}{|l|c|c|c|c|c|}
\hline \multirow{2}{*}{} & \multicolumn{5}{|c|}{$\mathrm{NaCl}$ concentration $(\mathrm{mM})$} \\
\cline { 2 - 6 } & 0.0 & 25 & 50 & 100 & 150 \\
\hline $\begin{array}{l}\text { Proline }\left(\mu \mathrm{mol} \mathrm{g}^{-1}\right) \\
\text { fresh weight }\end{array}$ & $0.806^{\mathrm{a}}$ & $2.546^{\mathrm{b}}$ & $3.876^{\mathrm{c}}$ & $5.812^{\mathrm{d}}$ & $7.536^{\mathrm{af}}$ \\
\hline
\end{tabular}

Mean values indicated by the same letter are not significantly different $(\alpha \leq 0.01)$.

\section{Protein profiles of the salt treated karkade seedlings}

The protein profiles of the salt treated karkade seedlings are presented in Table 7 . Comparing the protein profiles between control plants and those treated with different salt concentrations using SDS-PAGE showed that $\mathrm{NaCl}$ treatment induced changes in the protein patterns. It was found that the staining intensity of some protein bands was increased in salt-treated plants. Seedlings treated with 100 and $150 \mathrm{mM} \mathrm{NaCl}$ showed

Table 7

SDS-PAGE of total protein extracted from the leaves of salt treated karkade seedlings [Lane 1: Protein marker, lanes 2-6 are the treated seedlings with different concentrations $(0,25,50,100$ and $150 \mathrm{mM})$ of $\mathrm{NaCl}]$

\begin{tabular}{|c|c|c|c|c|c|c|}
\hline \multirow{2}{*}{ Band No. } & \multirow{2}{*}{ MW (KDa) } & \multicolumn{5}{|c|}{ NaCl concentration } \\
\cline { 2 - 6 } & & 0 & 25 & 50 & 100 & 150 \\
\hline 1 & 141.40 & + & + & + & + & + \\
\hline 2 & 117.75 & + & + & + & + & + \\
\hline 3 & 106.11 & + & + & + & + & + \\
\hline 4 & 100.19 & + & + & + & + & + \\
\hline 5 & 90.42 & + & + & + & + & + \\
\hline 6 & 56.73 & + & + & + & + & + \\
\hline 7 & 48.42 & - & - & - & + & + \\
\hline 8 & 42.81 & + & + & + & + & + \\
\hline 9 & 37.09 & - & - & - & + & + \\
\hline 10 & 32.00 & + & + & + & + & + \\
\hline 11 & 29.90 & + & + & + & + & + \\
\hline 12 & 26.55 & - & - & + & + & + \\
\hline 13 & 23.00 & - & - & + & + & + \\
\hline 14 & 14.15 & + & + & + & + & + \\
\hline 15 & & + & + & + & + & + \\
\hline
\end{tabular}


Table 8

$\mathrm{RF}$ values for peroxidase isozyme of the control $(0 \mathrm{mM} \mathrm{NaCl})$ and salt treated $(25,50,100$ and $150 \mathrm{mM} \mathrm{NaCl}$ ) karkade seedlings as analyzed using gel documentation program software

\begin{tabular}{|c|c|c|c|c|c|}
\hline \multirow{2}{*}{$\mathrm{Rf}$} & \multicolumn{5}{|c|}{$\mathrm{NaCl}$ concentration $\mathrm{mM}$} \\
\cline { 2 - 6 } & 0.0 & 25 & 50 & 100 & 150 \\
\hline 0.37 & + & + & + & + & + \\
\hline 0.42 & + & + & + & + & + \\
\hline 0.48 & - & - & + & + & + \\
\hline 0.55 & - & - & + & + & + \\
\hline
\end{tabular}

$\mathrm{RF}=$ Relative mobility of bands, $(+)$ Presence of bands and $(-)$ absence of bands.

higher staining intensity of bands compared with those of control ones. The salt treated seedlings were distinguished with five new bands of about 20.13, 23, 26.55, 37.09 and 48.42 , respectively.

\section{Peroxidase profiles of the salt treated karkade seedlings}

The peroxidase $\mathrm{Rf}$ values of the salt treated karkade seedlings (Table 8 and Fig. 2). Showed that salt stress increased the staining intensity of bands and induced some new bands. Treated seedlings with 100 and $150 \mathrm{mM} \mathrm{NaCl}$ showed higher staining intensity of bands compared with those of other ones. The salt treated seedlings with 50,100 and $150 \mathrm{mM} \mathrm{NaCl}$ were distinguished with two bands of about 0.48 and 0.55 Rf values, respectively (Table 8 and Fig. 2).

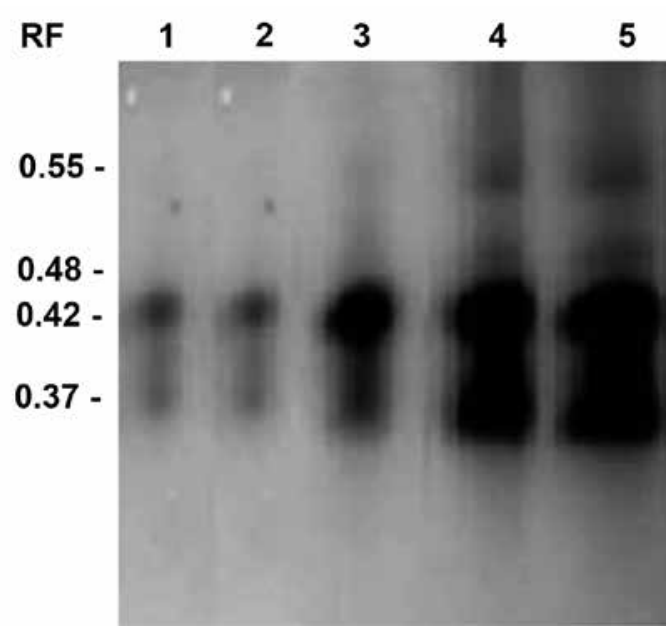

Fig. 2. Peroxidase isozyme profile of control $(0 \mathrm{mM} \mathrm{NaCl})$ and salt-treated $(25,50,100$ and $150 \mathrm{mM}$ $\mathrm{NaCl})$ karkade seedlings. Lane 1, Control and Lanes 2-5, salt-treated seedlings 


\section{DISCUSSION}

Most of the cultivated plants are sensitive to salt-stress, in which $\mathrm{NaCl}$ salinity has harmful effects on growth and development of plants. The reduction in germination process relies on salinity may be related to its negative effect on the physiological processes influencing seed germination $[8,13]$. Andriolo et al. [6] reported that salinity is the main cause of reduction the percentage and homogeneity of germination and dry weight of plants. Salinity delays plant growth by reducing photosynthesis effects. It includes closing stomata, reduction of water entrance into plants and a twofold reduction of plant weight [2]. Comparison of seedling lengths under salinity at different levels showed that when the salinity level increases length of seedlings decreases. In this relation it was reported that salinity reduces the growth of seedlings and the rate of reduction increases with increasing the level of salinity [8]. In the present study it was observed that salinity suppressed growth of seedlings. The suppression of growth may be related to the osmotic pressure which resulted in the limitation of water absorption by germinating seeds, subsequently the cell division, differentiation and length of seedlings decreased. Similar result was obtained by Savvas and Lenz [42], who reported that the reduction in fresh weight duo to salt stress is a normal phenomenon and it is related to the limitation of water uptake by germinating seeds. Leaf area was decreased. This might partially be attributed to the lower leaf water potential and a reduction in relative leaf water content, resulted in loss of turgor, which in turn causes stomatal closure and limits $\mathrm{CO}_{2}$ assimilation and reduced photosynthetic rate. This result agrees with the finding of Turner [47]. A marked growth reduction was also reported earlier to seedlings exposed to salt stress [36]. Some researcher have reported that vegetative growth of plants, i.e. shoot length, plant leaf area, fresh weight and dry weight were significantly reduced at salinities higher than $50 \mathrm{mM}[2,6,36]$. The results of this study demonstrate inhibition of the seed germination and reduction the growth of seedlings when expose to increase in salinity level. This study showed that photosynthetic pigment concentrations were reduced under the effect of salt stress. The decrease in Chl and tetrapyrroles content along with the increase of $\mathrm{NaCl}$ was also showed by Savvas and Lenz [42]. The results of this study are in agreement with those of Dagar et al. [18]. The decrease in chlorophyll concentration in salinized plants may be attributed due to activity increase in chlorophyll degrading enzyme chlorophyllase [3, 39]. Ion accumulation in the leaves also adversely affected chlorophyll concentration $[3,28]$. The decrease in carotenoids under salt stress leads to degradation of $\beta$-carotene and formation of zeaxanthins, which are apparently involved in protection against photo inhibition [27, 43]. As salinity adversely influenced the photosynthetic process, photosynthetic production (e.g. sugar) was inhibited $[18,42]$. It was found also that sugar content of leaves decreased in seedlings under $\mathrm{NaCl}$ stress [14]. One of the most important mechanisms by higher plants under salt-stress is the accumulation of compatible solutes such as proline. Proline accumulation in salt stressed plants is a primary defense response to maintain the osmotic pressure in the cells. Several reports show a significant role of proline in osmotic adjustment, protecting cell structure and its function in plants in 
salt-tolerant and salt-sensitive cultivars of many crops $[5,9,15]$. On the other hand, a positive correlation was determined between proline and tissue $\mathrm{Na}$ concentrations under salt stress $[9,10]$. Plants sterols are important components of the plant cell membrane regulating the permeability and modulating the activity of bond enzymes required for plant growth and development $[23,26]$. Sterol regulates the activity of the $\mathrm{Na}^{+} / \mathrm{K}^{+}$-ATPase in plant cells [23]. The osmotic effect resulting from soil salinity may cause disturbances in water balance of plant and inhibiting growth as well provoking stomata closure and reducing photosynthesis $[3,13]$. Plants respond by means of osmotic adjustment, normally by increasing the concentrations of $\mathrm{Na}^{+}$, although such accumulation of inorganic ions may produce important toxic effects and cell damage and inactivate both photosynthetic and respiratory electron transport [43, 44]. This limited osmotic adjustment was not sufficient to avoid water stress in the treated plants $[5,28]$. It was observed that high $\mathrm{Na} / \mathrm{Ca}$ ratio results in increased cell permeability $[31,49]$. Ion disorders caused by salinity was obtained when $\mathrm{NaCl}$ was applied in soil; the levels of $\mathrm{K}$ in plant were reduced in accordance with the antagonism between $\mathrm{Na}^{+}$and $\mathrm{K}^{+}[7,49]$. It was shown that excess of $\mathrm{NaCl}$ leads to the loss of $\mathrm{K}$ due to membrane depolarization by $\mathrm{Na}$ ions $[18,44]$. The increase in $\mathrm{Na}^{+}$ion content and decrease in $\mathrm{K}^{+}$ion uptake disturbs ionic imbalance as observed in most species exposed to salt stress [34]. The diminution of $\mathrm{K}^{+}$concentration in tissue may be related to the direct competition between $\mathrm{K}^{+}$and $\mathrm{N}^{+}$at plasma membrane. Inhibition of $\mathrm{Na}^{+}$on $\mathrm{K}^{+}$transport process in xylem tissues and/or $\mathrm{Na}^{+}$induced $\mathrm{K}^{+}$efflux from the roots [49]. High $\mathrm{Na}^{+}$accumulation in salt-sensitive foxtail millet cultivar and in lettuce roots have been reported [31], resulting in enhanced membrane damage, electrolyte leakage and oxidative damage. Wilson et al. [48] indicated that osmotic adjustment, accounted for decreases in the fresh weight and dry weight contents, increases in apoplastic water content and direct solute accumulation. MDA is produced when polyunsaturated fatty acids in the membrane undergo oxidation by the accumulation of free oxygen radicals. Lipid peroxidation is ascribed to oxidative damage and is often used as an indicator of increased damage [13, 24]. Comparing the protein profiles between control plants and those treated with different salt concentrations, using SDS-PAGE, showed that $\mathrm{NaCl}$ treatment induced changes in protein pattern. It was shown that the intensity of some protein bands was increased in salt-treated plants. The results obtained in this study are in agreement with those of Farida et al. [22], who reported that salt-stress induce alterations in protein profile and protease activity in mangrove (Bruguiera parvi). Peroxidases are enzymes related to polymer synthesis in the cell wall, as well playing an important role in prevention the oxidative damage caused by environmental stress to the membrane lipids [12]. Our results showed that salt stress elicits oxidative stress, measured as lipid peroxidation, as it has been seen in other species [32]. Salt stress increased peroxidase bands intensity and induced the appearence of some new bands. This may be associated with the potential role of this peroxidase in protecting lipid peroxidation. Salinity increases the content of $\mathrm{H}_{2} \mathrm{O}_{2}$ and induces oxidative stress in plant tissues [34]. Membrane injury under salt stress is related to increased production of highly toxic reactive oxygen species [28]. The results of our study are in agreement with those of Gaspar et al. [25], who 
reported that the increase in peroxidase due to salt, could be responsible for the ability to adapt to external stimulus. There are reports that salinity disrupts membrane permeability by peroxidation of the lipid membrane [12, 14, 27]. Salinity also increases the content of $\mathrm{H}_{2} \mathrm{O}_{2}$ and induces oxidative stress in plant tissues [40, 49]. Membrane injury under salt stress is related to increased production of highly toxic reactive oxygen species [28]. Our study proved that salt stress has a harmful effect on some morphological, physiological and molecular processes of seed germination in karkade (Hibiscus sabdariffa var. sabdariffa), injuring and/or influencing germination rate, vegetative growth, and photosynthetic pigments, sterol contents, the osmotic potential and protein profile of the plant.

\section{REFERENCES}

1. A.O.A.C. (1986) Official analysis of the association of official analytical chemist. 14th ed. Washington, D.C.

2. Akınc1, I. E., Akınc1, S., Yılmaz, K., Dikıc1, H. (2004) Response of eggplant varieties (Solanum melongena) to salinity in germination and seedling stages. New Zealand J. Crop Horticul. Sci. 32, 193-200.

3. Ali, H. M., Siddiqui, M. H., Basalah, M. O., Al-Whaibi, M. H., Sakran, A. M., Al-Amri, A. (2012) Effects of gibberellic acid on growth and photosynthetic pigments of Hibiscus sabdariffa L. under salt stress. Afr. J. Biotechnol. 11, 800-804.

4. Allakhverdiev, S. I., Sakamoto, A., Nishiyama, Y., Inaba, M., Murata, N. (2000) Photosystems I and II in Synechococcus sp. Plant Physiol. 123, 1047-1056.

5. Almansouri, M., Kine, T. J. M., Lutts, S. (2001) Effect of salt and osmotic stresses on germination in durum wheat (Triticum durum Desf.). Plant Soil 231, 243-254.

6. Andriolo, J. L., Luz, G. L., Witter, M. H., Godoi, R. S., Barros, G. T. (2005) Bortolotto OC Growth and yield of lettuce plants under salinity. Horticul. Brasil., Brasll. 23, 931-934.

7. Azevedo, N. A. D., Tabosa, J. N. (2000) Salt stress in maize seedlings: II. Distribution of cationic macronutrients and it's relation with sodium. Rev. Bras. Eng. Agric. Amb. 4, 165-171.

8. Azoo, M. M. (2009) Foliar application of riboflavin (Vitamin $\mathrm{B}_{2}$ ) enhancing the resistance of Hibiscus sabdariffa L. (deep red petals variety) to salinity stress. J. Biol. Sci. 9, 109-118.

9. Azooz, M. M., Shaddad, M. A., Abdel-Latef, A. A. (2004) The accumulation and compartmentation of proline in relation to salt tolerance of three sorghum cultivars. Ind. J. Plant Physiol. 9, 1-8.

10. Bajji, M., Lutts, S., Kient, J. M. (2001) Water deficit effects on solute contribution to osmotic adjustment as a function of leaf aging in three durum wheat (Triticum durum Defs.) cultivars performing differently in arid conditions. Plant Sci. 160, 669-681.

11. Bates, L. S., Waldren, R. P., Teare, I. D. (1973) Rapid determination of free proline for water-stress studies. Plant Soil 39, 205-207.

12. Bellani, L. M., Guarnieri, M., Scialabba, A. (2002) Differences in the activity and distribution of peroxidases from three different portions of germinating Brassica oleracea seed. Physiol. Plant 114, $102-108$.

13. Binzel, M. L., Reuveni, M. (1994) Cellular mechanisms of salt tolerance in plant cells. Hort. Rev. 16, 33-70.

14. Bor, M., Ozdemir, F., Turkan, I. (2003) The effect of salt stress on lipid peroxidation and antioxidants in leaves of sugar beet (Beta vulgaris L.) and wild beet (Beta maritima L.). Plant Sci. 164, 77-84.

15. Cha-um, S., Kirdmanee, C. (2009) Effect of salt stress on proline accumulation, photosynthetic ability and growth characters in two maize cultivars. Pak. J. Bot. 41, 87-98.

16. Cramer, G. R., Lauchli, A., Polito, V. S. (1985) Displacement of Ca from the plasmalemma of root cell. A primary response to salt stress. Plant Physiol. 79, 207-211. 
17. Czabator, F. J. (1962) Germination value: An index combining speed and completeness of pine seed germination. Forest Sci. 8, 386-395.

18. Dagar, J. C., Bhagwan, H., Kumar, Y. (2004) Effect on growth performance and biochemical contents of Salvadora persica when irrigated with water of different salinity. Ind. J. Plant Physiol. 9, 234-238.

19. El Naim, A. M., Ahmed, S. E. (2010) Effect of weeding frequencies on growth and yield of two roselle (Hibiscus sabdariffa L.) varieties under rain fed. Aust. j. basic appl. Sci. 4, 4250-4255.

20. El-Sherif, M. H., Sarwat, M. I. (2007) Physiological and chemical variations in producing roselle plant (Hibiscus sabdariffa L.) by using some organic farmyard manure. World J. Agricul. Sci. 3, 609-616.

21. Farag, R. S., Hallabo, S. A. S., Hewedi, F. M., Basyony, A. E. (1986) Chemical evaluator of rap seed - Feheseifen. Anstrichmi Hel. 88, 391-397.

22. Farida, A. K., Das, A. B., Mittra, B., Mohanty, P. (2004) Salt-stress induced alterations in protein profile and protease activity in the mangrove (Bruguiera parvi). Z Naturforsch C. 59, 408-414.

23. Fernandes, P., Cabral, J. M. S. (2007) Phytosterols: applications and recovery methods. Bioresou. Tech. 9, 2335-2350.

24. Flowers, T. J., Yeo, A. R. (1989) Effects of salinity on plant growth and crop yield. In: Cherry, J. H. (Ed.). Environmental Stress in Plants. Springer-Verlag: Berlin, pp. 101-119.

25. Gaspar, T., Penel, C., Castillo, F. J., Greppin, H. (2001) A two-step control of basic and acidic peroxidases and its significance for growth and development. Physiol. Plant 64, 418-423.

26. Hartmann, M. A. (2004) Sterol metabolism and function in higher plants. In: Daum, G. (Ed.) Lipid Metabolism and Membrane Biogenesis. Springer-Verlag: Heidelberg, pp. 183-211.

27. Heath, R., Packer, L. (1968) Photoperoxidation in isolated chloroplasts. I. Kinetics and stoichiometry of fatty acid peroxidation. Arch. Biochem. Biophys. 196, 385-395.

28. Hernandez, A., Almansa, M. S. (2002) Short-term effects of salt stress on antioxidant systems and leaf water deficits in leaves. Aust. J. Boil. Sci. 15, 413-428.

29. Khan, M. H., Panda, S. K. (2008) Alterations in root lipid peroxidation and antioxidative responses in two rice cultivars under NaCl-salinity stress. Acta Physiol. Plant 30, 81-89.

30. Laemmli, U. (1970) Cleavage of structural protein during the assembly of the head of bacteriophage T4. Nature 227, 680-685.

31. Levitt, J. (1980) Responses of Plants to Environmental Stresses. Vol. II, 2nd ed. Academic Press, New York, 607. p.

32. Luna, C., Gonzalez, C., Trippi, V. (1994) Oxidative damage caused by an excess of copper in oat leaves. Plant Cell Physiol. 35, 11-15.

33. Mahadevan, N., Shivali, K. P. (2009) Hibiscus sabdariffa Linn: An overview. Natural Product Radiance 8, 77-83.

34. Mandhania, S., Madan. S., Sawhney, V. (2006) Antioxidant defense mechanism under salt stress in wheat seedlings. Biol. Plant. 227, 227-231.

35. Metzner, R. H., Rau, H., Senger, H. (1965) Untersuchunger zur Synchronisierbarkeit einzelner-pigment-Mangel Mutanten Von Chlorella. Planta 65, 186-194.

36. Muhammad, Z., Hussain, F. (2010) Vegetative growth performance of five medicinal plants under $\mathrm{NaCl}$ salt stress. Pak. J. Bot. 42, 303-316.

37. Munns, R., Husain, S., Rivelli, A. R., James, R. A., Condon, A. G., Lindsay, M. P., Laguda, E. S., Schachtman, D. P., Hare, R. A. (2002) Avenues for increasing salt tolerance of crops, and the role of physiologically based selection traits. Plant and Soil 247, 93-105.

38. Murashige, T., Skooge, F. (1962) A revised medium for rapid growth and bioassays with tobacco tissue cultures. Plant Physiol. 15, 473-497.

39. Reddy, M. P., Vora, A. B. (2002) Changes in pigment composition, hill reaction activity and saccharides relations of pea leaves. Physiol. Plant 115, 251-257.

40. Rozbeh, F., Adel, F., Ali, A. (2015) Effect of salt stress on physiological and morphological parameters of rapeseed cultivar. J. Sci. Res. Develop. 2, 111-117.

41. SAS (2003) Proc User's Manual, Version 9.1., SAS Institute, Cary, NC, US. 
42. Savvas, D., Lenz, F. (2000) Effects of $\mathrm{NaCl}$ or nutrient-induced salinity on growth, yield, and composition of eggplants grown in rock wool. Scientia Horticulturae 84, 37-47.

43. Sharma, P. K., Hall, D. O. (1991) Interaction of salt stress and photo inhibition on photosynthesis in barley and sorghum. J. Plant Physiol. 138, 614-619.

44. Singh, P. K., Shahi, S. K., Singh, A. P. (2015) Effect of salt stress on physico-chemical changes in maize (Zea maize L.) plants in response to salicylic acid. Ind. J. Plant Sci. 4, 69-77.

45. Stigmann, H., Burgermeister, W., Francksen, H., Krogerrecklen, F. (1983) Manual of gel electrophoresis and isoelectrofocusing with the apparatus Planta-Phor. Inst. Biochem., Messeweg II. D-3300 Braunschweig West Germany.

46. Taleisnik, E., Peyrano, G., Arias, C. (1997) Response of Chloris gayana cultivars to salinity. 1. Germination and early vegetative growth. Trop. Grassl. 31, 232-240.

47. Turner, N. C. (1981) Techniques and experimental approaches for the measurement of plant water status. Plant Chem. 28, 350-356.

48. Wilson, J. R., Ludlow, M. M., Fisher, M. J., Schulze, E. E. (1989) Adaptations to water stress of the leaf water relations of four tropical forage species. Aust. J. Plant Physiol. 7, 207-220.

49. Zhu, J. K. (2003) Regulation of ion homeostasis under salt stress. Curr. Opin. Plant Biol. 6, 441-445. 